\title{
Education Systems and Multilateral Development Banks: International Practices and Perspectives
}

\author{
A. Morozkina, E. Sabelnikova ${ }^{1,2}$
}

\begin{abstract}
Aleksandra Morozkina - PhD student, National Research University Higher School of Economics, Junior research associate, Financial Research Institute; 3 Nastasyinsky Lane, 127006 Moscow, Russian Federation; E-mail: a.k.morozkina@gmail.com
\end{abstract}

Ekaterina Sabelnikova - Research associate, Centre for Fundamental Studies, Higher School of Economics, Senior expert, Center for Macroeconomic Analysis and Short-Term Forecasting; 47 Nakhimovsky Prospect, 117418 Moscow, Russian Federation; E-mail: esabelnikova@forecast.ru

This article examines the role of multilateral development banks (MDBs) in financing education development at the national level. It evaluates the share of national expenditures spent on education, analyzes loan structures by stage of education, and highlights key measures and instruments. In the context of the global economic slowdown, expected to continue for the long term, the most important objective is to identify new drivers of economic growth as traditional sources are exhausted. One of the main sources of economic growth is human capital, especially with regard to the gradual transition from an industrial economy to a service and knowledge economy. Human capital accumulation is particularly important in developing countries. Most developing countries face insuperable obstacles in building human capital accumulation particularly with regard to education development.

The potential contribution of MDBs to human capital accumulation has been underestimated and there is a lack of empirical research on this issue. An evaluation of current experience will help identify opportunities for MDBs to increase their role in education performance, which in turn could have a positive impact on economic growth in developing countries.

This article addresses this issue by studying MDBs' financing of education projects in emerging economies. The authors collected a database that includes information on the volume and structure of financing with a breakdown by education stage. It was based on more than 500 projects funded by key MDBs. Sources included loan and grant agreements, project interim reports and project completion reports. The authors calculated an average annual ratio of MDB education financing to public expenditure for each country in the final selection.

Results showed that the ratio of average annual MDBs allocations to average government expenditures on education is relatively low - between $1.5 \%$ and $4.0 \%$ for most countries. The largest share can be seen in relatively small countries, where government expenditures stay at low levels. Large developing countries such as Brazil, India, Indonesia and Mexico are leading in terms of absolute volumes of financing from MDBs. The authors also show that most projects during period researched aimed at reducing inequality,

${ }^{1}$ Research is conducted as a part of Basic Research Program of Higher School of Economics in 2016 (T3-17). Authors would like to express their sincere gratitude to the anonymous referee for valuable comments and recommendations.

${ }^{2}$ The editorial board received the article in June 2016. 
developing infrastructure, improving teacher qualifications and reforming the management of education system. The authors also give recommendations for the BRICS New Development Bank.

Key words: education financing; multilateral development banks; developing countries

For citation: Morozkina A., Sabelnikova E. (2017) Education Systems and Multilateral Development Banks: International Practices and Perspectives. International Organisations Research Journal, vol. 12, no 1, pp. 24-42 (in Russian and English). DOI: 10.17323/1996-7845-2017-01-24. 


\section{Introduction}

Most developing countries face insuperable obstacles in their efforts to solve the problem of poor education development. The problem is not only in the lack of funding, but also in the widespread, unfilled demand for best practices, exchange of cultural experiences, and broad education promotion among the population. In these circumstances the importance of international organizations grows due to their ability to promote best practices, provide consulting services, and monitor accordance between allocated funds and the purposes for which they are allocated. Most sovereign loans for education are provided on favourable conditions, and the rate does not often exceed 2-3\% [ADB, 2011], although it may vary depending on the amount borrowed and the loan terms.

Currently, education loans do not account for a significant share of the total amount of loans provided by major multilateral development banks (Table 1), varying from $8.5 \%$ in the World Bank (about 3.5 bln USD) and $4 \%$ in the Asian Development Bank (just under 1 bln. USD) to a complete absence in the European Bank for Reconstruction and Development loan portfolio.

Table 1: Multilateral Development Bank Loan Portfolios by Sector, \%, 2014

\begin{tabular}{|l|c|c|c|c|c|}
\hline \multicolumn{1}{|c|}{ Industry Sector } & ADB & AfDB & EBRD & IADB & $\begin{array}{c}\text { World } \\
\text { Bank }\end{array}$ \\
\hline Agriculture and natural resources & 5.9 & 11.6 & 13.0 & 3.7 & 7.5 \\
\hline Education & 4.0 & 2.3 & - & 1.3 & 8.5 \\
\hline Energy & 26.9 & 29.3 & 19.0 & 8.2 & 16.4 \\
\hline Finance & 14.2 & 17.9 & 32.0 & 23.0 & 4.9 \\
\hline Health care and social security & 0.1 & 5.9 & - & 14.6 & 8.2 \\
\hline Industry and trade & 1.9 & 0.9 & 13.0 & 4.7 & 4.4 \\
\hline Public management & 9.7 & - & - & 16.4 & 21.6 \\
\hline Transport and communication & 24.9 & 20.4 & 23.0 & 17.4 & 17.9 \\
\hline $\begin{array}{l}\text { Water supply and other municipal infrastructure } \\
\text { and services }\end{array}$ & 9.3 & 5.7 & - & 10.4 & 10.6 \\
\hline Multisector & 3.2 & 5.9 & - & 0.3 & - \\
\hline Total & 100 & 100 & 100 & 100 & 100 \\
\hline
\end{tabular}

Source: author's calculations based on [ADB Annual report, 2014; AfDB Group Annual report, 2014; IADB Annual report, 2014; EBRD's Annual report, 2014; WB Annual Report, 2014].

A review of the studies leads us to the conclusion that the investigation is mostly concentrated on assessing the contribution of a single MDB to education system 
performance, often through the application of case studies including the cases of Korea and Mexico [Lee, 2010]; Namibia, Nicaragua, and Egypt [Jilles, 2010]; Bangladesh [Quibria, 2010]; and Uganda and Thailand [Collins, Rhoads, 2015]. Estimates of the effectiveness of loans and grants provided by the World Bank have been included in a large number of works, notably WB, 2002, and Heyneman, 2003. However, most of the studies consider only the World Bank and overlook the importance of other MDBs. In addition, few if any shed light on the problem of an integrated assessment of MDBs' contributions to the financing of education systems in developing countries.

To a large extent this is due to a lack of data required to measure the real contribution of MDBs in education funding by country. Thus, in this paper we aimed to assess MDBs' contributions to education funding in developing countries, investigate loan structure by stage of education, highlight key measures and instruments based on analysis of best practices (case studies), and to set out recommendations for the recently initiated New Development Bank (NDB).

\section{Methodology}

In this part we investigate the contribution of multilateral development banks' education system financing by country. To solve this problem it seems rational to calculate the share of MDBs' financing of the education system. For this purpose, the average total education funding provided by an MDB should first be calculated, and secondly it should be attributed to the average annual public expenditure on education.

Due to high volatility in the amount of annual tranches, we considered the mean for 2012-2014. We examined public expenditure rather than total expenditure for two reasons. Firstly, in a number of countries there is no actual data on private spending. Secondly, MDBs carry out expenditure in a centralized way, similar to state participation in education funding. We used World Bank as data source for public expenditure.

There are no databases on education projects for individual MDBs listing terms, countries names and amounts borrowed, so the main object is to create such a database.

The final sample of multilateral development banks comprised four major institutions: the World Bank, the Asian Development Bank, the African Development Bank and the Inter-American Development Bank.

We also considered the European Bank for Reconstruction and Development, the Eurasian Development Bank and the Islamic Development Bank. The first two did not launch any education projects, and the third does not publish reports on individual projects, thereby precluding further analysis. The data sources include loan proposals, 
and progress and final reports on project implementation. A database with 575 education projects was established as a result.

When creating the preliminary version of the database we pursued the following strategy. At first we considered all projects that meet two basic criteria:

- the project contains measures aimed at education, reinforced by appropriate funding;

- the project was implemented in 2012-2014.

As a result, 349 projects were included, of which 224 projects are provided by the World Bank, 53 by the Asian Development Bank, 23 by the African Development Bank, and 49 by the Inter-American Development Bank.

The database structure is as follows:

- project title;

- the name of the borrowing country;

- project terms;

- type of financing;

- total amount of project funding;

- funding for the education system through the project;

- funding at individual educational stages (primary education, secondary education, vocational education, tertiary education). ${ }^{3}$

Careful review shows that there are two types of project supported by the MDB, which allows two measures for project funding to be included in the database. The first type of project is focused entirely on education, with the entire loan targeting the development of various stages of education and improvement of education system management (this item is represented in most of projects, amounting to $10-15 \%$ of total funding on average). The second type of project is aimed at social development or economic recovery as a whole (this is the case for loans or grants provided for the elimination of consequences of natural and technogenic disasters). In such projects, the share of education funding is generally low, and does not exceed $20 \%$.

We should put special emphasis on the following:

1. In cases where a project report did not specify the annual distribution of tranches, it was assumed to follow a uniform distribution of tranches during the period. This hypothesis seems to be justified, because in some projects containing detailed information on tranche distribution, tranches are actually allocated in that way. The number of these projects reached 102 .

${ }^{3}$ The study used the categorization of the education system to levels in accordance with the International Standard Classification of Education, which is applied by all MDBs to provide harmonization of standards. 
2. In cases where a project report did not specify the annual distribution of tranches at education stages, it was assumed to follow a uniform distribution of tranches by stages. The number of these projects reached 24.

3. In cases where a project contained measures aimed not only at education development (e.g. assistance in natural disaster recovery), and where there was no information in the progress report according the distribution of funding by areas, it was assumed to follow a uniform distribution by areas. The number of these projects was 20 .

On the basis of these criteria, a table containing public expenditure on education and MDB financing was prepared. We could not find information on public expenditure in 2012-2014 for nine countries. They were consequently excluded from further consideration.

As a result, a final list of countries was obtained on the basis of two criteria:

- countriesforwhich MDBs' share in education financing exceedsa predetermined expert threshold of $2 \%$;

- countries for which this threshold is below $2 \%$, but which are leaders in the total amount of MBD financing. They include major developing countries featuring significant public investment in education.

\section{Results}

The results show that multilateral development banks play a relatively small role in countries' expenditure on education (Table 2). In the table we split financing from the World Bank and other multilaterals, because the World Bank has more projects than other multilateral development banks. Besides, regional development banks finance only countries from their region, and it is easy to identify a country with the bank that finances projects on its territory.

Small countries such as Guinea-Bissau and Malawi generally have a larger share of MDB financing in public expenditure, because of the low level of public expenditure. At the same time, large developing countries such as Brazil, India, Indonesia, and Mexico are among the leading recipients in terms of absolute volume, although share of loans and grants of MDBs amounts to less than one percent of public expenditure on education in these countries. 
Table 2: MDB loans and countries' public expenditure on education, 2012-2014, mln USD

\begin{tabular}{|c|c|c|c|c|c|}
\hline Countries & $\begin{array}{c}\text { Average } \\
\text { annual WB } \\
\text { financing on } \\
\text { education, } \\
2012-2014\end{array}$ & \begin{tabular}{|c|} 
Average \\
annual \\
financing \\
from regional \\
MDBs on \\
education, \\
2012-2014
\end{tabular} & \begin{tabular}{|c|} 
Average \\
annual \\
financing \\
from MDBs \\
on education, \\
2012-2014, \\
TOTAL
\end{tabular} & $\begin{array}{c}\text { Average } \\
\text { annual public } \\
\text { expenditure } \\
\text { on education, } \\
2012-2014\end{array}$ & $\begin{array}{l}\text { Share of MDBs } \\
\text { financing } \\
\text { in public } \\
\text { expenditure, \% }\end{array}$ \\
\hline Bangladesh & 132.9 & 188.6 & 321.5 & 2839 & 11.3 \\
\hline Botswana & - & 69.2 & 69.2 & 1168 & 5.9 \\
\hline Brazil & 234.6 & - & 234.6 & 142721 & 0.2 \\
\hline Burundi & 5.4 & - & 5.4 & 145 & 3.7 \\
\hline Vietnam & - & 80.2 & 80.2 & 9822 & 0.8 \\
\hline Ghana & 8.5 & 92.3 & 100.8 & 3079 & 3.3 \\
\hline Guinea-Bissau & 3.8 & - & 3.8 & 21 & 17.8 \\
\hline Honduras & 1.5 & 10.8 & 12.3 & 1087 & 1.1 \\
\hline Georgia & 14.4 & - & 14.4 & 314 & 4.6 \\
\hline India & 268.2 & 23.0 & 291.2 & 70077 & 0.4 \\
\hline Indonesia & 116.5 & 37.0 & 153.5 & 30964 & 0.5 \\
\hline Cambodia & 1.4 & 10.0 & 11.4 & 268 & 4.2 \\
\hline Congo & 16.3 & 14.5 & 30.8 & 674 & 4.6 \\
\hline Laos & 1.3 & 7.3 & 8.6 & 500 & 1.7 \\
\hline Libya & 1.1 & - & 1.1 & 49 & 2.2 \\
\hline Mauritania & 2.8 & 2.9 & 5.7 & 155 & 3.7 \\
\hline Madagascar & 9.0 & - & 9.0 & 246 & 3.7 \\
\hline Malawi & 5.3 & 61.5 & 66.7 & 296 & 22.5 \\
\hline Mexico & 134.2 & - & 134.2 & 73439 & 0.2 \\
\hline Mozambique & 28.5 & - & 28.5 & 989 & 2.9 \\
\hline Mongolia & 0.4 & 9.8 & 10.2 & 480 & 2.1 \\
\hline Nepal & 37.6 & - & 37.6 & 861 & 4.4 \\
\hline Pakistan & 227.7 & 15.1 & 242.8 & 5514 & 4.4 \\
\hline Ruanda & 15.1 & 7.0 & 22.1 & 361 & 6.1 \\
\hline $\begin{array}{l}\text { Sao Tome } \\
\text { and Principe }\end{array}$ & 0.3 & - & 0.3 & 16 & 2.1 \\
\hline Tanzania & 34.8 & 36.2 & 71.0 & 1673 & 4.2 \\
\hline Tunisia & 23.0 & 86.9 & 109.9 & 2809 & 3.9 \\
\hline Uganda & 26.8 & 75.4 & 102.2 & 588 & 17.4 \\
\hline Philippines & 61.0 & 45.7 & 106.7 & 5752 & 1.9 \\
\hline Sri Lanka & 21.1 & 45.9 & 67.0 & 1180 & 5.7 \\
\hline Ethiopia & 90.8 & - & 90.8 & 2143 & 4.2 \\
\hline Jamaica & 3.1 & 12.9 & 16.0 & 874 & 1.8 \\
\hline
\end{tabular}

Source: author's calculations. 
African and Asian regions are the major recipients of MDB education financing, which can be explained by the large number of developing countries in these regions. In Asia most of the resources go to primary and secondary education (Table 3). Bangladesh, as one of the poorest countries in the region, has the largest share of MDB financing in public expenditure on primary and secondary education. When looking at the breakdown by education stage, the largest recipient of primary education financing is the Philippines, and second largest is Laos.

Table 3: MDB financing and public expenditure on education in Asian key recipients, 2012-2014, \%

\begin{tabular}{|l|c|c|c|c|c|c|c|c|}
\hline \multirow{2}{*}{ Country } & \multicolumn{9}{|c|}{$\begin{array}{c}\text { Share of MDB financing in public } \\
\text { expenditure, }\end{array}$} & \multicolumn{3}{c|}{ Share of MDB financing on education, \% } \\
\cline { 2 - 10 } & Prim. & Sec. & Tert. & Vocat. & Prim. & Sec. & Tert. & Vocat. \\
\hline Bangladesh & 6.7 & 4.8 & 0.6 & 0.3 & 53.8 & 38.6 & 5.2 & 2.4 \\
\hline Vietnam & 0.6 & 0.4 & 0.7 & 0.1 & 31.6 & 23.4 & 41.7 & 3.3 \\
\hline Georgia & 1.2 & 4.2 & 1.2 & 0.0 & 18.6 & 62.9 & 18.6 & 0.0 \\
\hline India & 0.2 & 0.2 & 0.1 & 0.1 & 43.9 & 33.3 & 11.5 & 11.4 \\
\hline Indonesia & 0.3 & 0.1 & 0.0 & 0.1 & 58.8 & 23.9 & 8.1 & 9.2 \\
\hline Cambodia & 0.0 & 3.7 & 0.5 & 0.0 & 0.0 & 87.9 & 12.1 & 0.0 \\
\hline Kyrgyz & 0.1 & 0.0 & 0.0 & 0.7 & 7.8 & 5.2 & 0.0 & 87.0 \\
Republic & & & & & & & & \\
\hline Laos & 0.1 & 1.6 & 0.0 & 0.0 & 7.7 & 90.7 & 1.6 & 0.0 \\
\hline Mongolia & 0.2 & 3.3 & 0.7 & 0.2 & 5.3 & 75.3 & 16.0 & 3.5 \\
\hline Nepal & 2.2 & 0.9 & 0.6 & 0.6 & 51.5 & 20.4 & 13.4 & 14.8 \\
\hline Pakistan & 2.2 & 1.4 & 0.8 & 0.4 & 46.1 & 29.2 & 16.6 & 8.0 \\
\hline Samoa & 1.3 & 1.3 & 0.0 & 0.0 & 50.0 & 50.0 & 0.0 & 0.0 \\
\hline Philippines & 1.2 & 0.7 & 0.0 & 0.0 & 62.5 & 37.5 & 0.0 & 0.0 \\
\hline Sri Lanka & 0.5 & 3.8 & 0.9 & 1.4 & 7.9 & 58.2 & 13.2 & 20.7 \\
\hline
\end{tabular}

Source: author's calculations.

In Africa an interesting picture can be observed. In 2012-2014 the African Development Bank financed mostly tertiary and vocational education projects. Therefore, despite the region's poverty and low level of primary education development, the share of tertiary education financing is high (Table 4). This can be explained by the large amounts of financing that were directed to the development of primary education within the Millennium Development Goals framework, which included only primary education. This created some bias towards primary education financing at the expense 
of tertiary education, so some countries started to borrow from development institutions to finance other stages of education.

Among African countries, MDBs play the largest role in financing primary education on Sao Tome and Principe, secondary education in Guinea-Bissau, tertiary education in Malawi, and vocational education in Eritrea.

Table 4: MDB financing and public expenditure on education in African key recipients, 2012-2014, \%

\begin{tabular}{|l|c|c|c|c|c|c|c|c|}
\hline \multirow{2}{*}{ Country } & \multicolumn{3}{|c|}{ Share of MDB financing in public } & \multicolumn{3}{c|}{ Share of MDB financing on education, \% } \\
\cline { 2 - 9 } & Prim. & Sec. & Prim. & Sec. & Prim. & Sec. & Prim. & Sec. \\
\hline Angola & 0.1 & 0.0 & 1.5 & 0.0 & 6.1 & 0.0 & 93.9 & 0.0 \\
\hline Botswana & 0.0 & 0.0 & 5.9 & 0.0 & 0.0 & 0.0 & 100 & 0.0 \\
\hline Burundi & 1.5 & 2.2 & 0.0 & 0.0 & 39.9 & 58.9 & 1.2 & 0.0 \\
\hline Ghana & 0.0 & 0.0 & 3.1 & 0.2 & 0.0 & 0.0 & 94.0 & 6.0 \\
\hline Guinea-Bissau & 0.0 & 17.8 & 0.0 & 0.0 & 0.0 & 100 & 0.0 & 0.0 \\
\hline Kenia & 0.0 & 0.0 & 1.6 & 0.0 & 0.0 & 0.0 & 100 & 0.0 \\
\hline Congo & 0.0 & 0.0 & 0.0 & 2.2 & 0.0 & 0.0 & 0.0 & 100 \\
\hline Mauritania & 0.0 & 0.0 & 0.0 & 3.7 & 0.0 & 0.0 & 0.0 & 100 \\
\hline Madagascar & 3.7 & 0.0 & 0.0 & 0.0 & 100 & 0.0 & 0.0 & 0.0 \\
\hline Malawi & 1.3 & 0.5 & 20.8 & 0.0 & 5.9 & 2.0 & 92.1 & 0.0 \\
\hline Morocco & 0.0 & 0.2 & 0.8 & 3.3 & 0.0 & 4.0 & 19.3 & 76.7 \\
\hline Mozambique & 0.3 & 0.2 & 0.4 & 0.3 & 24.5 & 18.0 & 36.0 & 21.5 \\
\hline Nicaragua & 1.1 & 0.0 & 0.0 & 0.0 & 100 & 0.0 & 0.0 & 0.0 \\
\hline Ruanda & 0.0 & 5.2 & 4.9 & 2.8 & 0.0 & 40.5 & 37.8 & 21.6 \\
\hline Sao Tome \\
and Principe & 6.6 & 0.0 & 0.0 & 0.0 & 100 & 0.0 & 0.0 & 0.0 \\
\hline Senegal & & & & & & & & \\
\hline Tanzania & 0.6 & 0.5 & 2.6 & 4.5 & 7.6 & 6.4 & 31.8 & 54.2 \\
\hline Tunisia & 0.0 & 0.0 & 0.8 & 3.1 & 0.0 & 0.0 & 20.9 & 79.1 \\
\hline Uganda & 1.7 & 3.1 & 4.2 & 0.8 & 17.3 & 32.0 & 42.4 & 8.4 \\
\hline Eritrea & 0.0 & 0.0 & 0.0 & 63.9 & 0.0 & 0.0 & 0.0 & 100 \\
\hline Ethiopia & 4.1 & 0.1 & 0.1 & 0.0 & 96.4 & 2.4 & 1.2 & 0.0 \\
\hline
\end{tabular}

Source: author's calculations. 


\section{MDB's measures aimed at education development}

Most projects supported by MDBs are aimed at dealing with key problems in the education sphere and contain a standard set of measures. The following problems, which will be analyzed in this chapter, are:

- High level of inequality in access to education (income, gender, territorial inequality);

- Low level of infrastructure development;

- Low qualification of teachers;

- Low quality of education management;

- Lack of incentives to receive education;

- High cost of education;

- Linguistic and cultural differences.

To solve the problem of the high level of inequality in access to education, MDBs pursue an engagement policy for discriminated groups by financial stimulation, including grants for vulnerable populations. During the implementation of the "Secondary Education Sector Development Program" in Bangladesh, schools enrolling girls were provided with priority financing for modernization of classrooms and other infrastructure [ADB, 2013]. In Kyrgyzstan, special attention was paid to the description of career opportunities for girls in modernized teaching and learning materials [ADB, 2012]. A challenging measure is the revision of learning materials in order to make it equally interesting for girls and boys, by including descriptions of male and female characters in tasks. This measure is included, for example, in the "Education Improvement Project" in Armenia [WB, 2016a]. The project includes gender analysis of the Armenian school curriculum and textbooks, and suggestions to modernize them. These measures increase the engagement of girls in the education process at the primary and secondary levels.

One of the key measures aimed at the development of infrastructure is financing the construction of new education facilities or the modernization of existing ones. Some projects envisage the building of new classrooms [ADB, 2013], the modernization of equipment, or the building of new schools in remote and disadvantaged areas (project "Education Sector Reconstruction" in Burundi [WB, 2012]).

To improve teachers' skills, MDBs provide additional training, modernization of teaching materials, and working spaces. In particular, during implementation of the "Vocational training improvement project" in India, 19.5 thousand instructors of vocational education institutions were retrained, primarily on the basis of newly established institutes for training instructors [WB, 2016c]. During the implementation 
of "Education Sector Reconstruction" in Burundi [WB, 2012], new in-service programs and devices to train teachers, schools directors and inspectors were introduced.

Key measures when dealing with the problem of low quality of education management are decentralization of education process and the coordination of policy on different levels (depending on form of government). Special regional government agencies [IADB, 2015], or links between different levels of government (for example between federal, municipal and regional such as the "General Education Quality Improvement Project" in Ethiopia [WB, 2016b]) can be established. Also, MDBs finance the introduction of basic disciplines, narrowing of the gap between different levels of education, increasing the importance of practice in the curriculum, and updating learning and teaching materials (which is especially important for vocational training). ${ }^{4}$

To deal with the lack of stimulus to get an education, MDBs conduct meetings with parents of potential pupils (for example, "Early Childhood Education Project" in the Dominican Republic [WB, 2013]). There are also special grants for children from rural areas and poor families. For example, one of the measures introduced in the "Secondary Education Sector Development Program" in Bangladesh [ADB, 2013] was the establishment of stipends program for poor people - this stipend was granted to students who met the criteria of poverty and agreed to the conditions of attendance, remaining unmarried, and demonstrating fair academic performance.

Among other goals, MDBs also aim to reduce costs of education, and eventually to ensure free universal primary education. Also there are special grants during implementation of MDB's projects.

One of the key measures in dealing with linguistic and cultural differences is improving the accessibility of learning materials to minorities by translation, adaptation and provision of a sufficient amount (an optimal proportion of 1 textbook per pupil). Thus, during the implementation of the "General Education Quality Improvement Project" in Ethiopia (2009-2013) more than 120 new textbooks titles were developed, some of them in minorities' languages [WB, 2016b]. Also, the pupil-textbook ratio increased to 1.2 textbooks per pupil.

Examples of projects that contain the measures listed above are presented in Annex A. The projects were selected from the group of completed projects, because project completion reports contain the most comprehensive list of detailed measures that were realized during the project implementation.

${ }^{4}$ For example, "General Education Quality Improvement Project" in Ethiopia [WB, 2016b] contains measures on the development and provision of textbooks and teacher guides for mathematics, biology, chemistry, and physics. In Jamaica, "Support for Education Reform" [IADB, 2015] envisages analysis and revision of curricula in secondary education with the aim of better aligning it with primary education and the standards of the exit exam. 
Building on the established database, we calculated the number and total value of projects that contain certain measures (Table 5). The results show that the largest number of projects are aimed at tackling inequality (152 projects), infrastructure development (145 projects), improving teachers' skills (133 projects), and improving management of the education process (112 projects).

Table 5: Structure of financial support of MDBs by key problems

\begin{tabular}{|l|c|c|c|c|c|c|c|c|}
\hline \multicolumn{1}{|c|}{ Development Bank } & \multicolumn{2}{|c|}{ AsDB } & \multicolumn{2}{c|}{ AfDB } & \multicolumn{2}{c|}{ IADB } & \multicolumn{2}{c|}{ WB } \\
\hline & Number & $\begin{array}{c}\text { Vol., } \\
\text { mln } \\
\text { USD }\end{array}$ & Number & $\begin{array}{c}\text { Vol., } \\
\text { mln } \\
\text { USD }\end{array}$ & Number & $\begin{array}{c}\text { Vol., } \\
\text { mln } \\
\text { USD }\end{array}$ & Number & $\begin{array}{c}\text { Vol., } \\
\text { mln } \\
\text { USD }\end{array}$ \\
\hline $\begin{array}{l}\text { Lack of incentives } \\
\text { to get education }\end{array}$ & 10 & 1020 & 0 & 0 & 2 & 40 & 29 & 6080 \\
\hline High cost of education & 15 & 1916 & 2 & 115 & 6 & 58 & 7 & 1054 \\
\hline $\begin{array}{l}\text { Linguistic and cultural } \\
\text { differences }\end{array}$ & 5 & 224 & 0 & 0 & 3 & 152 & 11 & 801 \\
\hline $\begin{array}{l}\text { Low qualification } \\
\text { of teachers }\end{array}$ & 23 & 1489 & 10 & 274 & 16 & 568 & 84 & 15292 \\
\hline $\begin{array}{l}\text { Low level } \\
\text { of infrastructure } \\
\text { development }\end{array}$ & 32 & 3117 & 14 & 323 & 22 & 1394 & 77 & 13338 \\
\hline $\begin{array}{l}\text { Unequal access } \\
\text { to education (income, } \\
\text { gender, territorial } \\
\text { inequality) }\end{array}$ & 32 & 3128 & 11 & 314 & 12 & 1568 & 97 & 17904 \\
\hline $\begin{array}{l}\text { Low quality } \\
\text { of education } \\
\text { management }\end{array}$ & 31 & 2405 & 8 & 165 & 21 & 1546 & 52 & 8879 \\
\hline $\begin{array}{l}\text { Post-conflict/ natural } \\
\text { disaster recovery }\end{array}$ & 6 & 142 & 0 & 0 & 0 & 0 & 4 & 841 \\
\hline
\end{tabular}

Source: author's calculations.

\section{Cooperation with New Development Bank}

Cooperation between MDBs and the newly established New Development Bank (NDB) on a wide range of education issues may contribute to resolving education problems in the most successful emerging countries. Despite the fact that the first loans of NDB are in the green energy sector, given that the goal of NDB was to support sustainable development ("mobilize resources for infrastructure and sustainable development projects in BRICS and other emerging economies and developing countries" [NDB, 2014]), support for education projects can also be expected. NDB can become a valuable partner for existing development banks in the education sphere. 
Firstly, NDB can become a platform for the cultivation of new ideas of MDBs participation in dealing with education problems - for example, designing primary and secondary education programs aimed at the development of creativity and fresh thinking. In recent years more attention in schools has been paid to creativity and critical thinking, as these features are essential for building a career in an innovation economy. This trend can be seen in themes of conferences and workshops [OECD, 2013], academic works [Lucas, Claxton, Spencer, 2013], and the establishment of organizations aimed at the promotion of creative forms of education (for example, the British charity Creativity, Culture and Education (CCE)). Modern curricula with rare exceptions do not promote creative and critical thinking, so there is a need for new approaches to the development of school curricula and learning materials.

Secondly, cooperation with NDB could contribute to resolving common issues of BRICS countries, including a mismatch between education and the labour market. In recent years the World Bank has introduced a project in India aimed at reforming vocational education so that it becomes more demand-driven, which partly resolves the mismatch issue. Also, education reform and improving the quality of education may help to overcome the middle-income trap, which is relevant to all BRICS countries [Grigoriev, Morozkina, 2013].

Thirdly, NDB can share the BRICS' experience of using new mechanisms of multilateral cooperation in the education sphere, such as the BRICS Network University, the Universities League, and the Universities Summit. These mechanisms together with MDBs can gain from pooling experience. These practices should be analyzed and applied to other international groups and associations where possible.

Thus, New Development Bank can add to the activities of MDBs not only by financing additional projects, but also by bringing forward new ideas for dealing with educational issues.

\section{Conclusion}

In this article we look at the role of multilateral development banks in financing education on the national level. We showed that their share in funding is relatively low in comparison to countries' public expenditure. Most projects are aimed at resolving such issues as improving of teacher qualification, reducing inequality, and reforming the management of education systems.

The international community takes an active part in dealing with education sector problems, which is demonstrated by the inclusion of the education theme (Goal 4: Ensure inclusive and quality education for all and promote lifelong learning [UN, 2015]) in Sustainable Development Goals (SDGs). The expansion of the activities 
of development banks in the education sphere, including the implementation of more projects in disadvantaged economies, and launching the second stages of successful projects, may contribute to achieving SDGs. Thus, multilateral development banks have a great capacity to expand their impact on global issues in the education sphere, in particular by expanding coverage of countries and areas within countries, as well as by cooperating with new mechanisms and development institutions. 


\section{References}

ADB (2011) Summary of ADB Financial Instruments and Approval Procedures. Available at: http://www.adb.org/documents/summary-adb-financial-instruments-and-approvalprocedures (accessed 13 May 2016).

ADB (2012) Kyrgyz Republic: Second Vocational Education and Skills Development Project. Available at: http://www.adb.org/projects/documents/second-vocationaleducation-and-skills-development-project-kyrgyz-republic-pam (accessed 13 May 2016).

ADB (2013) Bangladesh: Secondary Education Sector Development Program. Project Completion report. Available at: http://www.adb.org/projects/documents/secondaryeducation-sector-development-program-pcr (accessed 13 May 2016).

ADB (2014a) Kyrgyz Republic: Vocational Education and Skills Development Project. Project Completion report. Available at: http://www.adb.org/projects/documents/ vocational-education-and-skills-development-project-pcr (accessed 13 May 2016).

ADB (2014b) Annual report. Official Web Portal of the Asian Development Bank. Available at: http://www.adb.org/documents/series/adb-annual-reports (accessed 13 May 2016).

AfDB Group (2014) Annual report. Official Web Portal of the African Development Bank. Available at: http://www.afdb.org/en/documents/publications/annual-report/ (accessed 13 May 2016).

Collins C., Rhoads R. (2015) The World Bank and higher education in the developing world: The cases of Uganda and Thailand. Available at: http://dx.doi.org/10.1016/S14793679(08)00007-8 (accessed 13 May 2016).

EBRD (2014) Annual report. Official Web Portal of the European Reconstruction and Development Bank. Available at: http://www.ebrd.com/news/publications.html (accessed 13 May 2016).

Grigoriev L., Morozkina A. (2013) BRICS: Different Economies, Similar Problems. Russia in Global Affairs, no 2, pp. 26-40.

Heyneman S.P. (2003) The history and problems in the making of education policy at the World Bank 1960-2000. International Journal of Educational Development, vol. 23, pp. 315-337. 
IADB (2014) Annual Report. Official Web Portal of the Inter-American Development Bank. Available at: http://publications.iadb.org/handle/123456789/2/discover?scope=123456789 $/ 1 \&$ thumbnail $=$ true $\&$ rpp $=5 \&$ page $=0 \&$ group_by $=$ none \&etal $=0$ (accessed 13 May 2016).

IADB (2015) Jamaica: Support for Education Sector Reform III. Loan Proposal. Available at: www.iadb.org/Document.cfm?id=39886123 (accessed 13 May 2016).

Jilles J. (2010) The Power of Persistence Education System Reform and Aid Effectiveness. Available at: http://www.equip123.net/docs/E2-Power_of_Persistence.pdf (accessed 13 May 2016).

Lee K. (2010) Borrowing from the World Bank for Education: Lessons from Korea and Mexico. Journal of International Cooperation in Education, vol. 13, no 2, pp. 49-71.

Lucas B., Claxton G., Spencer E. (2013) Progression in Student Creativity in School. First Steps Towards New Forms of Formative Assessments.OECD Education Working Paper, no 86. Available at: http://www.oecd-ilibrary.org/education/progression-in-studentcreativity-in-school_5k4dp59msdwk-en (accessed 13 May 2016).

NDB (2014) Articles of Agreement of the New Development Bank. Official Web Portal of the Sixth BRICS Summit. Available at: http://brics6.itamaraty.gov.br/media2/pressreleases/219-agreement-on-the-new-development-bank-fortaleza-july-15 (accessed 13 May 2016).

OECD (2013) Educating for Innovation in Asia: Theory, Evidence and Practice. Available at: http://www.oecd.org/edu/ceri/educatingforinnovationinasia.htm (accessed 13 May 2016).

Qiubria M. (2010) Aid Effectiveness in Bangladesh: Is the Glass Half Full or Half Empty? Available at: http://www.economics.illinois.edu/docs/seminars/Aid-Effectiveness-inBangladesh.pdf (accessed 13 May 2016).

UN (2015) Transforming our world: the 2030 Agenda for Sustainable Development. Available at: https://sustainabledevelopment.un.org/post2015/transformingourworld (accessed 13 May 2016).

WB (2002) The Role and Effectiveness of Development Assistance: Lessons from World Bank Experience. Available at: http://siteresources.worldbank.org/DEC/Resources/ roleofdevelopment.pdf (accessed 13 May 2016). 
WB (2012) Burundi: Education Sector Reconstruction Project. Project Completion Report. Available at: http://documents.worldbank.org/curated/en/645221468014430427/ pdf/NonAsciiFileName0.pdf (accessed 13 May 2016).

WB (2013) Dominican Republic: Early Childhood Education Project. Project Performance Assessment Report. Available at: http://documents.worldbank.org/curated/ en/732341468249029215/pdf/782750PPAR0P0500Box377377B00PUBLIC0.pdf(accessed 13 May 2016).

WB (2014) Annual Report. Official Web Portal of the World Bank. Available at: siteresources. worldbank.org/EXTABOUTUS/Resources/29707-1280852909811/IBRD_Jun_14.pdf (accessed 13 May 2016).

WB (2016a) Armenia: Education Improvement Project. Implementation Status \& Results Report. Available at: http://documents.worldbank.org/curated/en/375181468008133998/ pdf/ISR-Disclosable-P130182-05-05-2016-1462451146387.pdf (accessed 13 May 2016).

WB (2016b) Ethiopia: General Education Quality Improvement Project II. Implementation Status \& Results Report. Available at:http://documents.worldbank.org/curated/ en/673461468021619889/pdf/ISR-Disclosable-P129828-03-14-2016-1457974202849.pdf (accessed 13 May 2016).

WB (2016c) India: Vocational Training Improvement Project. Implementation Status \& Results Report. Available at: http://documents.worldbank.org/curated/ en/412951468040492672/pdf/ISR-Disclosable-P099047-04-26-2016-1461679110899.pdf (accessed 13 May 2016). 


\begin{tabular}{|c|c|c|}
\hline 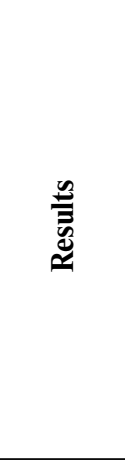 & 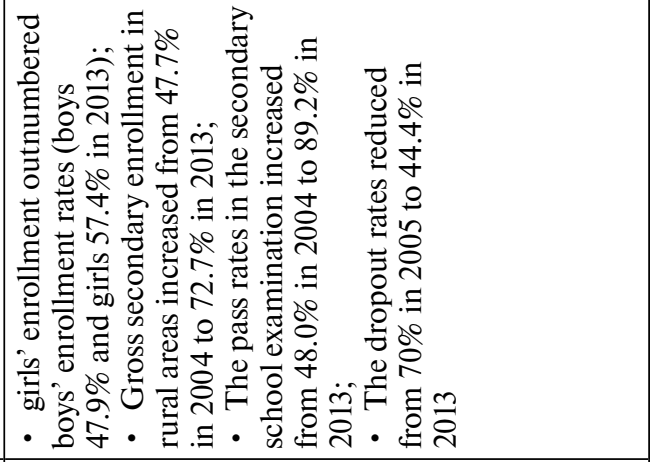 & 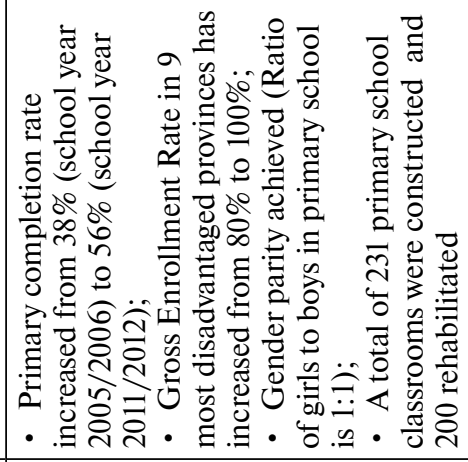 \\
\hline 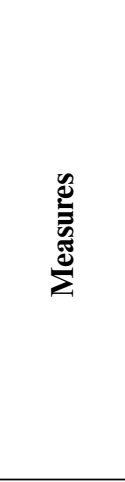 & 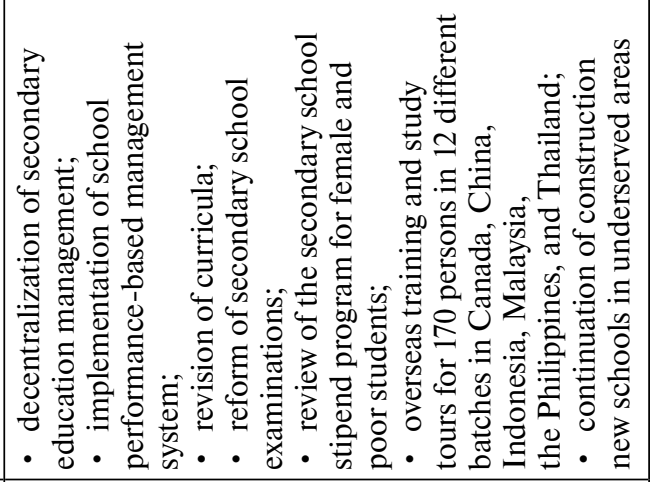 & 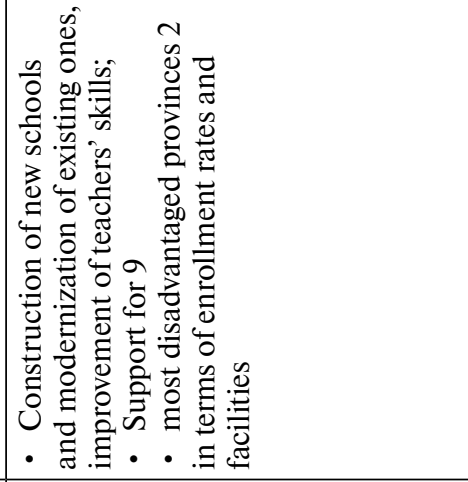 \\
\hline छ్రీ & 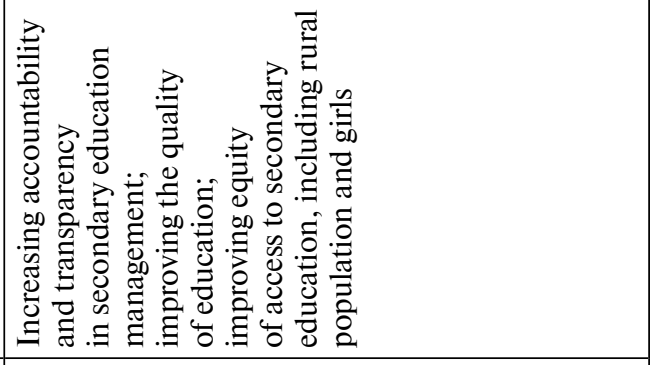 & 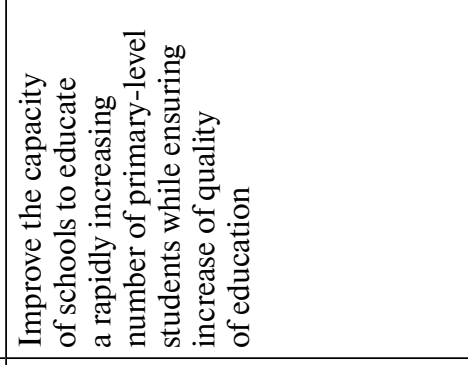 \\
\hline 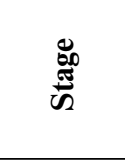 & 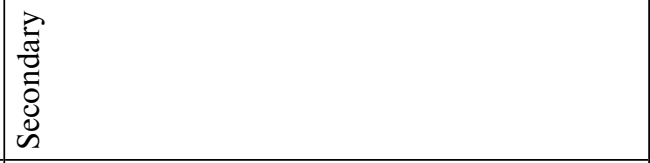 & 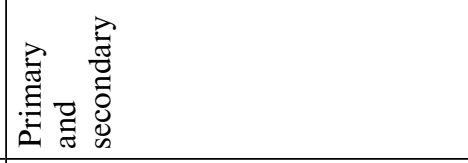 \\
\hline 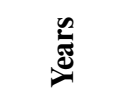 & 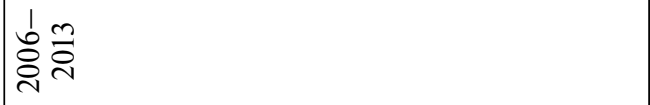 & 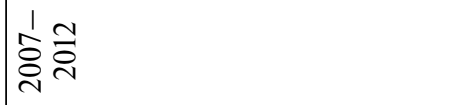 \\
\hline 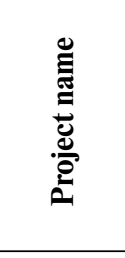 & 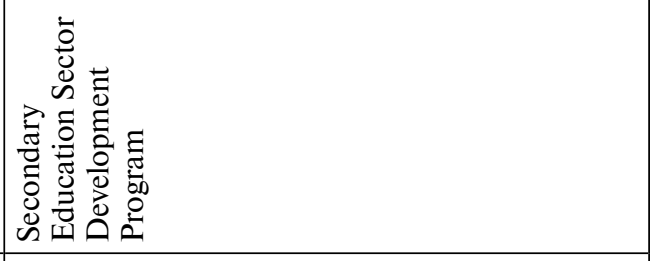 & 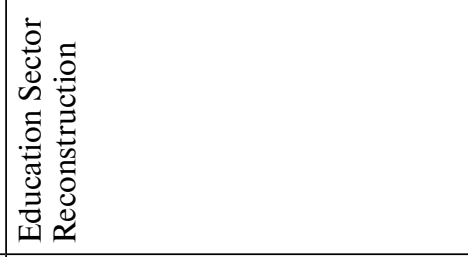 \\
\hline 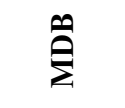 & 产 & $\stackrel{\infty}{3}$ \\
\hline 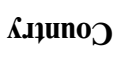 & 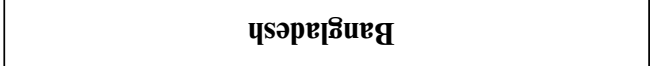 & !pun.nng \\
\hline
\end{tabular}




\begin{tabular}{|c|c|c|c|}
\hline 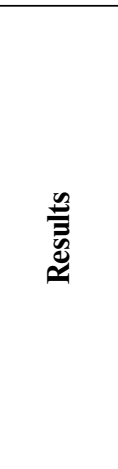 & 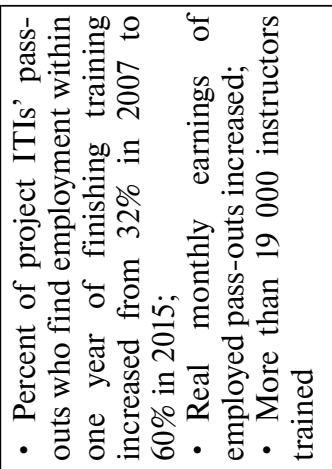 & 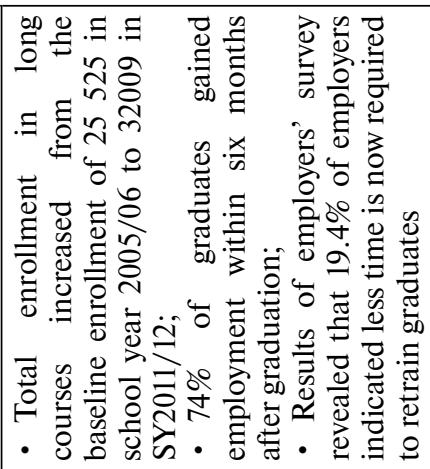 & 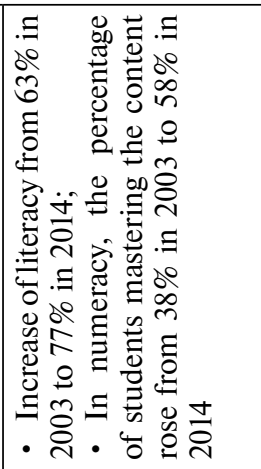 \\
\hline 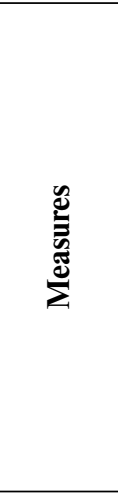 & 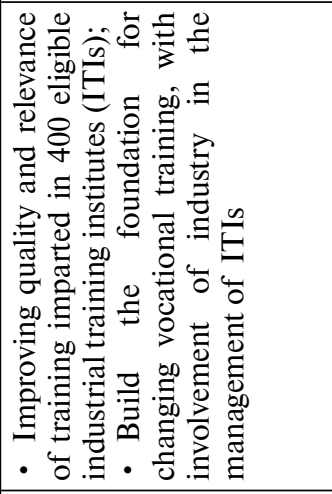 & 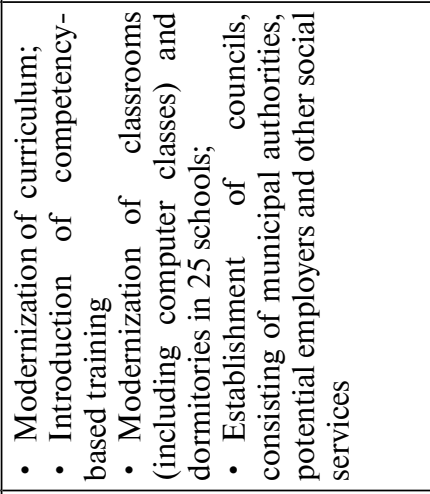 & 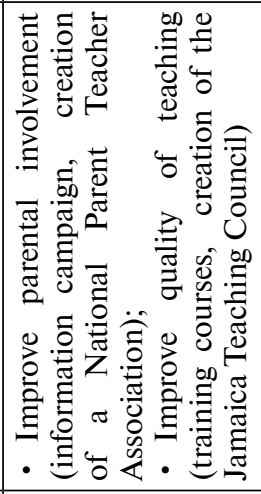 \\
\hline હू & 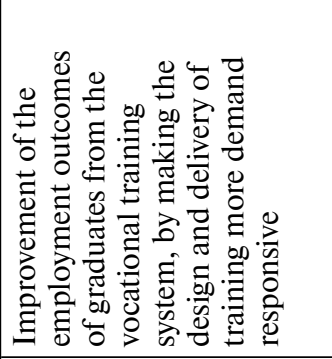 & 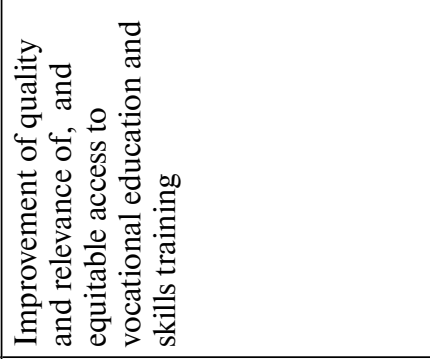 & 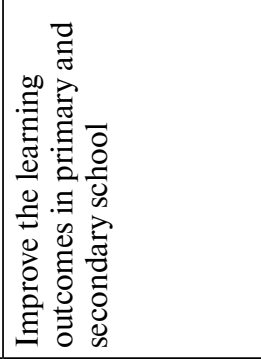 \\
\hline$\underset{\varpi}{\infty}$ & 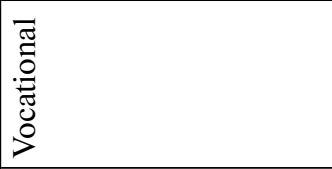 & 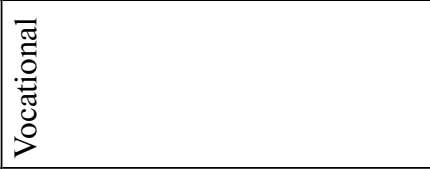 & 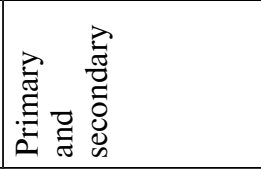 \\
\hline 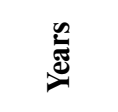 & 茪菅 & 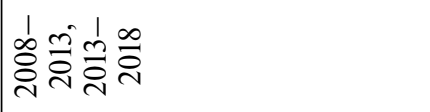 & 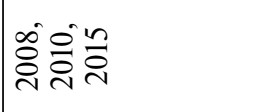 \\
\hline 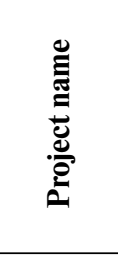 & 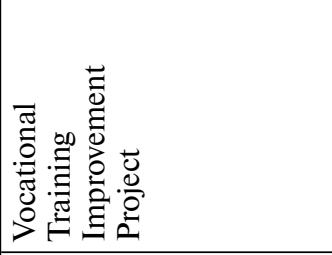 & 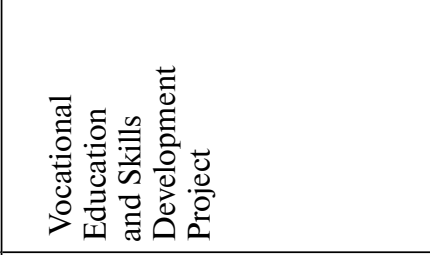 & 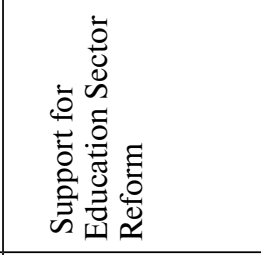 \\
\hline$\hat{\Sigma}$ & $\sum^{\infty}$ & जै & 空 \\
\hline К.лиกоว & в!рuI & 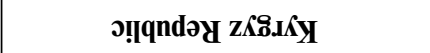 & вэ!६uвр \\
\hline
\end{tabular}

